\title{
A perfect storm: embodied workers, emplaced corporations, and delayed reflexivity in a Canadian 'Risk Society'
}

\author{
Deborah Davis Jackson ${ }^{1}$ \\ Earlham College, USA
}

\begin{abstract}
At the turn of the 21st century, an occupational disease epidemic began to unfold in Sarnia, Ontario, home to the petrochemical complex known as Canada's 'Chemical Valley.' Given the long latency periods for these diseases, the hazardous exposures that produced them would have occurred over a period of decades during the latter 20th century. This suggests a paradox: what accounts for unionized Canadian men working for decades in conditions that posed such grave risks to their health? Or, put in terms of Ulrich Beck's compelling and influential model: given that Chemical Valley during the second half of the 20th century constituted a quintessential "risk society" of the modern West, where were the forces of "political reflexivity" - resistance leading to change - typically provoked by the excesses of such societies? In this article, I seek to resolve this paradox with a political ecology approach that focuses on workers' embodied experience in the microenvironment of their workplace and community, as well as on the material and social emplacement of petrochemical facilities in the region. The analysis reveals a 'perfect storm' of converging ecological, cultural, political, and economic conditions that allowed local corporations to achieve extraordinary power. Consequently, even as activism for occupational and environmental justice was effecting change in similar industrial centers throughout Ontario and the Great Lakes region, these changes failed to take hold in Chemical Valley. The article concludes by suggesting that those $20^{\text {th }}$ century power dynamics have continued into the 21st century, where reflexivity delayed might well have atrophied into reflexivity denied.
\end{abstract}

Keywords: embodiment, emplacement, risk society, petrochemical corporations, industrial workers, Canada, Great Lakes region

\section{Résumé}

À la fin du XXIe siècle, une épidémie de maladies professionnelles a commencé à se développer à Sarnia, en Ontario, qui abrite le complexe industriel pétrochimique connu sous le nom de «Chemical Valley (vallée chimique)» du Canada. En raison des longues périodes de latence pour ces maladies, les expositions dangereuses qui les ont produites se seraient produites au cours des dernières décennies au cours du XXème siècle. Cela suggère un paradoxe: qu'est-ce qui explique les hommes canadiens syndiqués qui travaillent pendant des décennies dans des conditions qui posaient des risques si graves pour leur santé? Nous plaçons cela dans le modèle de risque convaincant et influent d'Ulrich Beck: puisque Chemical Valley était une «société du risque» par excellence au cours de la seconde moitié du XXe siècle, où se trouvaient les forces de la "réflexivité politique" - la résistance menant au changement - généralement provoquée par les excès de telles sociétés? Dans cet article, je cherche à résoudre ce paradoxe avec une approche d'écologie politique qui se concentre sur l'expérience incarnée des travailleurs dans le micro-environnement de leur lieu de travail et de

\footnotetext{
${ }^{1}$ Dr. Deborah Davis Jackson, Research Professor, Anthropology, Earlham College, 801 National Road W, Richmond, IN, USA 47374. Email: jacksde "at" earlham.edu. The research on which this article is based was made possible by several Professional Development Grants from Earlham College, as well as an Understanding Canada - Canadian Studies 201011 Faculty Research Grant ICCS \#625-2-20, and a New Directions Initiative Grant from the Great Lakes Colleges Association. I much appreciate the helpful comments from two anonymous JPE reviewers and the generous assistance of $J P E$ editors, and I am grateful to Meredith Beed for providing a Spanish translation of the abstract and keywords. In addition, I wish to thank Bridget Hayden, JoAnn Martin, and Michael R. Jackson for useful suggestions on earlier versions of the manuscript. Thanks to James Brophy and Margaret Keith, along with Sandra Kinart, for providing me with friendship and encouragement, as well as access to information, resources, and people that proved vital to the success of this project. And finally, I am most grateful to the women and men who allowed me to interview them and who helped me understand their lives.
} 
leur communauté, ainsi que sur la mise en place matérielle et sociale d'installations pétrochimiques dans la région. L'analyse révèle une «tempête parfaite» de conditions écologiques, culturelles, politiques et économiques convergentes qui ont permis aux entreprises locales de disposer d'un pouvoir extraordinaire. En conséquence, même si l'activisme en faveur de la justice au travail et de l'environnement entraînait des changements dans des centres industriels similaires en Ontario et dans la région des Grands Lacs, ces changements ne se sont pas concrétisés à Chemical Valley. L'article conclut en suggérant que ces dynamiques de pouvoir du 20ème siècle se sont poursuivies jusqu'au 21ème siècle, où la réflexivité retardée pourrait bien s'être atrophiée en refus de la réflexivité.

Mots-clés: mode de réalisation, emplacement, société à risque, sociétés pétrochimiques, travailleurs de l'industrie, Canada, région des Grands Lacs

\section{Resumen}

A la vuelta del siglo 21, una epidemia de enfermedades ocupacionales comenzó a revelarse en Sarnia, Ontario, sede del complejo petroquímico conocido como el 'Valle Químico' de Canadá. Dado que los periodos de estado latente son largos para estas enfermedades, las exposiciones peligrosas que los produjeron habrían ocurrido durante un período de décadas durante la segunda mitad del siglo 20. Esto indica una paradoja: ¿Qué interés tendría para los hombres canadienses agremiados que trabajaron durante décadas en condiciones que planteaban graves riesgos a su salud? O, puestos en términos del modelo convincente e influyente de Ulrich Beck: ¿Dado que durante la segunda mitad del siglo 20, el Valle Química de Sarnia constituyó una 'sociedad del riesgo' prototípica del moderno Oeste, donde estaban las fuerzas de "reflexividad política"- la resistencia que conduce el cambio - típicamente producido por los excesos de dichas sociedades? En este artículo, busco resolver esta paradoja con un enfoque de ecología política que se centre en las experiencias encarnadas aportadas por los trabajadores en los micro-medio ambientes de su lugar de trabajo y su comunidad, tanto en el emplazamiento material como social de las instalaciones petroquímicas en la región. El análisis revela una 'tormenta perfecta' de las condiciones ecológicas, políticas y condiciones convergentes que permitieron las corporaciones locales lograr un poder extraordinario. Por consiguiente, incluso cuando el activismo laboral y la justicia ambiental estaban efectuando un cambio en varios centros industriales similares en todo Ontario y en la región de los Grandes Lagos, estos cambios no llegaron a tomar asiento en el Valle Químico. El artículo concluye observando que esas dinámicas de poder del siglo 20 han continuado hasta el siglo 21, donde la reflexividad demorada bien podría haberse atrofiado en la negación de la reflexividad.

Palabras clave: anthropología encarnada, emplazamiento, sociedad de riesgo, corporaciones petroquímicas, trabajadores industriales, Canadá, región de los Grandes Lagos

\section{Introduction}

Lambton County in Southwestern Ontario comprises fields and farmlands, villages and towns, the city of Sarnia, and one of the heaviest concentrations of petrochemical plants in Canada. Located in the heart of the Great Lakes, Sarnia-Lambton lies along the St. Clair Channel ${ }^{2}$ which runs north-south, connecting Lake Huron with Lake Erie, as well as dividing Canada to the east from the United States to the west (Figure 1). Petrochemical facilities began locating there in the early 1940s, and by the early 1960s prominent political and business leaders informally dubbed this industrial complex 'Chemical Valley'; the moniker caught on, evoking local pride in the innovative products developed there, as well as in the economic prosperity these new industries brought to the region. There was little recognition in those early years of the darker realities inherent in petrochemical production: that is, the threats these operations posed to the environment and, more acutely, to the health and well-being of residents in the region, as well as workers in the plants.

Sarnia-Lambton represents, in many ways, a classic "risk society" as theorized by German sociologist Ulrich Beck (1992, 1995). In contrast to "traditional" industrial production, the facilities that comprise Chemical Valley are of the type Beck calls "risk" industries - those that produce toxic chemicals, nuclear radiation, and other such hazardous substances and processes. These risk hazards can be distinguished from those produced by traditional industrial means not only by the degree of harm they can inflict - they are deadlier

\footnotetext{
2 This term refers to three waterways - the St. Clair River, Lake St. Clair, and the Detroit River - combined.
} 
- but also by their geographic reach - they are able to move easily beyond the industrial facility and its immediate surroundings, outward to remote locations. In addition, such threats as nuclear radiation and toxic chemical emissions are often "invisible and hard to identify in everyday life" (Beck 1992: 3) and the damage they cause to humans and the environment is often delayed. Consequently, in a risk society the public becomes increasingly anxious as the devastating results of toxic substances in the air, water, and food supply become obvious. At the same time, research about such risks is controlled almost exclusively by scientists and technocrats in a process Beck calls a "politics of knowledge" that leaves citizens without sufficient information - at least during the early stages - to take action and effect change. These conditions cannot, however, be sustained indefinitely under "the special conditions of developed wealthy democracies" because, "once citizens realize that the guardians of rationality and order also legalize threats to survival, all hell breaks loose politically" (p. 3). While widespread systemic change is rarely, if ever, achieved, such activism can bring about small incremental changes that accrue over time to "make exemplary progress possible" (p. 6).

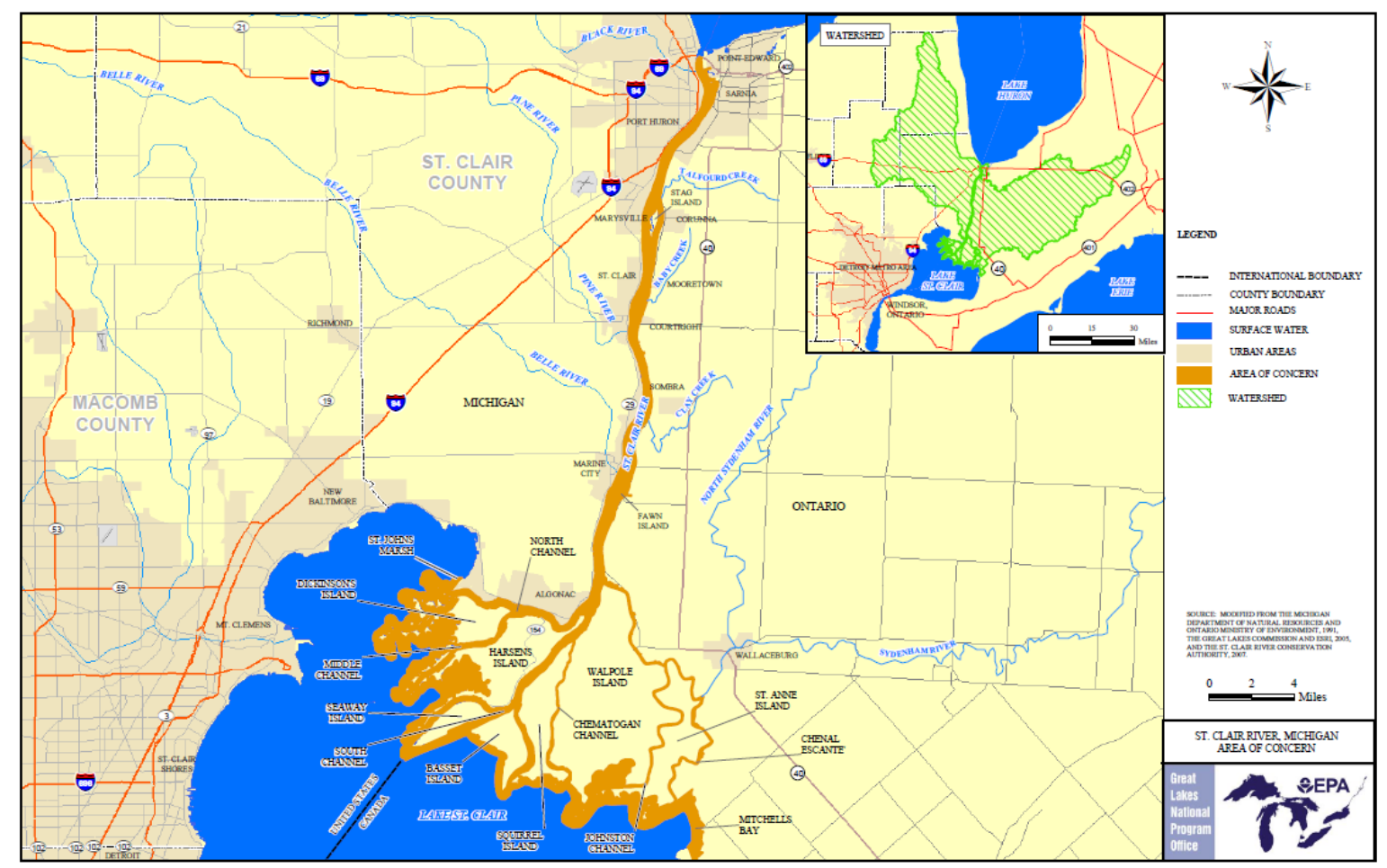

Figure 1: St. Clair River, with Lake Huron and Sarnia to the North, and Detroit/Lake St. Clair to the South. Source: EPA.

As I argue below, Sarnia-Lambton, though a quintessential risk society in nearly all respects, deviates from the model in one highly significant way: that is, despite the social and environmental protest movements that roiled the body politic in Canada and United States during the 1970s and into the 1980s, Sarnia-Lambton remained for the most part unaffected. In this sense, the political reflexivity one might expect given the presence there of a vast petrochemical complex was delayed for decades beyond counterparts elsewhere in North America. The full extent of this deviation and its effects on workers and their families is explored throughout this article. I begin, however, by considering some signs of activist challenges to local conditions that I encountered early in my research, and that seemed at the time, after more than fifty years' delay, finally to be gathering momentum. 
When I first arrived in Sarnia in 2007, several important initiatives for environmental and occupational justice were underway. Activists from the nearby Aamjiwnaang First Nation were raising awareness about environmental injustices there through regular "toxic tours" of their reserve; a new documentary film examining the effects of environmental pollution on children's health and featuring Sarnia as a major "toxic hotspot" in Canada (Cohen 2007) was screened at a local community center with political leaders and media present; Ecojustice (the legal arm of the Sierra Club in Canada) published a scathing exposé on the extent of air pollution from local plants and its potential effects on the health of Sarnia-Lambton residents (MacDonald and Rang 2007); occupational health researchers were raising awareness throughout the wider community on effects of hazardous workplace conditions; and, a citizens' group had formed to call attention to occupational health issues. Most promising of all was a development I learned about the first time I met with local occupational and environmental advocates. It was a morning in early July, 2007, and they had just returned from a meeting with Sarnia's mayor and various other officials, excited to announce that plans for a Lambton Community Health Study had been approved. The planned study was to involve a variety of community leaders and stakeholders, with the goal of assessing health effects associated with exposure to industrial emissions. It therefore represented a crucial first step - one that had been sought by local activists for years - toward holding corporations responsible for the consequences of their pollution. Given all these developments, I thought that perhaps political reflexivity had come to Sarnia-Lambton. This impression turned out, however, to be shortlived.

My research totaled 14 months, stretching over nine years: six months in 2007, followed by two months during each of four summers: 2008, 2010, 2013, and 2016. By the end of that period, most if not all of the initiatives that had seemed so promising in 2007 had dwindled in strength or ceased all-together. This article provides an account of factors that prevailed during the second half of the 20th century and converged, I argue, into a 'perfect storm' that allowed local petrochemical corporations to wield extraordinary power - a circumstance that has continued into the 21st century. The story begins with the occupational health crisis that was well underway by the time I began my research and that had its origins in past, on the shop floors of Chemical Valley.

The most prominent disease to which workers began succumbing in large numbers around the turn of the 21st century was mesothelioma (Keith and Brophy 2004). Considered "a 'sentinel' occupational cancer" (Payne and Pichora 2009: 148), mesothelioma serves as a warning of hazardous workplace conditions - in this case, asbestos exposure. It is therefore striking that this disease has been reported to occur among Lambton County workers at a rate four times that of the rest of Ontario combined (Payne and Pichora 2009), raising questions not only about asbestos exposures, but also about working conditions more generally. This occupational health crisis, then, provides a salient and poignant connection between the present and the past, as the afflicted workers literally carry within their bodies toxic substances from exposures on the shop-floors of decades ago. I therefore begin my analysis of Chemical Valley with an in-depth look at the experience of workers on the front lines of Sarnia's industrial production during the earlier stages of their work life in the 20th century. I then consider the larger political economic context of the period that shaped and constrained workers' experience, with an emphasis on the deep emplacement of petrochemical corporations in the local ecology and community. These conditions converged in a perfect storm that, I argue, allowed local corporations to wield extraordinary power, including control over their representation in the regional media. The result: despite the fact that forces of social and political change - the political reflexivity predicted by Beck - were occurring elsewhere in Ontario and throughout the Great Lakes region, the risk industries of Chemical Valley were able to thwart such efforts in Sarnia-Lambton and continue their harmful practices virtually unopposed.

\section{Theories and methods: a political ecology approach}

Although Beck's general approach - a deeply critical analysis of a form of industrial capitalism that ultimately entails "self endangerment [of humans] and the devastation of nature" (Beck 1995: 2) - provides a compelling framework for my analysis here, it remains inadequate for that purpose in two important ways. First, in discussing the negative impacts of toxic substances on humans, Beck emphasizes the public at large while giving little attention to industrial workers as a class ("risk positions are not class positions" [Beck 1992: 
3]). ${ }^{3}$ Second, his macro-sociological perspective is too general and abstract to be useful in sorting out the unique conditions, processes and power dynamics explored here. Rather, a political ecology approach is needed that considers the lived experience of workers, salient features of the regional ecology, and the dynamics of the local political economy. Beck's complex and wide-ranging theory, then, is best considered among "concepts from broader schools of thought" that can be "mobilized" to "explain otherwise confounding socialenvironmental outcomes" of concern to political ecologists (Robbins 2012: 84). That is the approach taken here (cf. Dwyer and Minnegal 2006; Little 2013).

When I began the interviews for this project in June of 2008, one of the first people I spoke with was Donna ${ }^{4}$, whose husband had died of mesothelioma four years prior to our conversation. Given the attention that occupational health advocates had recently brought to this local crisis, as well as the rise of a vocal advocacy group for families of those lost to occupational disease, I was taken aback when Donna offered me the following advice:

Your best bet for finding out about health impacts is to interview the widows of workers who have died. It's only then that his family gets angry enough — and has nothing left to lose - that they're willing to talk. (Interview, June 9, 2008)

Although I did in fact encounter the kind of resistance Donna had predicted, I was able during my 14 months of fieldwork, spanning nine years, to learn a great deal about life and work in Chemical Valley. During this time, I consumed local media, combed the archives for information about the petrochemical industry, attended political and community events, and consulted previous studies and documentary films about Sarnia-Lambton. In addition, I engaged in numerous informal conversations, as well as more formal recorded interviews, with occupational health researchers, environmental activists, health care workers, a plant manager, and several retired workers and widows of workers.

Given the long latency period for mesothelioma and other lethal diseases of the current epidemic, which can be up to 40 years, I focused my research primarily on conditions in the plants during 1960s, 1970s, and 1980s, when little information was available to the public (including workers) on health risks associated with industrial exposures. Throughout this period, although the petrochemical plants went from their peak of productivity in the early 1960s through a gradual decline that began in the 1970s and continued into the 1980s, the local corporations managed to retain their central place in the economic, social, cultural, and political life of Sarnia-Lambton throughout. In analyzing these conditions and their consequences, I draw on perspectives from philosophy, anthropology, and geography, along with political ecology, to emphasize the dynamic interplay of meaning and materiality in the embodied experience of workers, as well as in the emplaced power of corporations in Chemical Valley. ${ }^{5}$ We begin with workers' embodied experience of occupational hazards on the shop floors of Chemical Valley.

\section{Embodiment: senses, affects, materialities}

My exploration of the realities of workers' lives is informed by phenomenological approaches to embodiment such as that of medical anthropologist Thomas Csordas (1994). Csordas calls for a "radical role for the body", considered in terms of "lived experience", foregrounding "temporally/historically informed sensory presence and engagement" (Csordas 1994: 10). Similarly, Margaret Lock and Judith Farquhar (2007) seek to move "beyond the body proper" in their edited volume of that title, pointing to a growing "anthropology

\footnotetext{
${ }^{3}$ Beck does, however, recognize those who live "next to the refineries and chemical factories in the industrial centers of the Third World" (Beck 1992: 41) as being the most severely disadvantaged. Although Canada is hardly a Third World country, there is a community in Sarnia-Lambton that has suffered disproportionately from its proximity to industrial production. I refer to Aamjiwnaang (mentioned above), a First Nations reserve around which the petrochemical industry has clustered, putting residents there in positions of high risk to their health and well-being (see Jackson 2010, 2011; Mackenzie, Lockridge and Keith 2004; Murphy 2013; Scott 2008; Wiebe 2016).

${ }^{4}$ I have changed the names of interviewees to protect their privacy.

${ }^{5}$ For a different, yet complementary, approach to risk, sensory perception of hazards, and emplacement, see Reno (2011).
} 
of the senses" literature that is contributing important insights to the "turn toward embodied lifeworlds" that their volume represents (Lock and Farquhar 2007: 9).

Other phenomenologically inspired scholars in the field of anthropology engage in more sustained attention to sensory experience, such as Paul Stoller's call for a "sensuous scholarship" that emphasizes the importance of "incorporating into ethnographic works the sensuous body - its smells, tastes, textures, and sensations" (Stoller 1997: xv). Similarly, geographer Paul Rodaway proposes a "sensuous geography" in which "the experience of the senses is the ground base on which a wider geographical understanding can be constructed" (Rodaway 1994: 3), and in her exploration of the effects of mega-projects on Canadian communities, environmental historian Joy Parr highlights "sensuous ways of interacting with the world" that are "best distinguished as phenomenological or corporeal embodiments" (Parr 2010: 10).

These sensory-centered studies in the fields of cultural anthropology, human geography, and environmental history share one more feature that is central to the analysis here: each recognizes close interconnections between sensory experience and affective response. Affect has received increased scholarly attention in recent years (e.g., Besnier 1990; Skoggard and Waterston 2015; Thien 2005). For the present analysis, I find concepts put forth by Kathleen Stewart (2007) and Roberto Barrios (2017) to be exceptionally cogent. Stewart focuses on "everyday embodied encounters that, while intimate, are at the same time public" (Stewart 2007: 3) - encounters through which "ordinary affects" are enacted. A compatible approach is taken by Barrios, who defines affect as "a sensory experience that is felt by the body in relation to another, human or otherwise" (Barrios 2017: 5), and that emerges "in relation to socially structured and meaning-laden relationships with people and things" through a process he terms "ecology of affect" (Barrios 2017: 6).

Even as these phenomenological concepts of sensory and affective experience maintain a focus on human agency, they also engage the world beyond humans. In this way, they are compatible with recent political ecology approaches that incorporate materials, substances, and things into their analyses, such as Jane Bennett's notion of "vibrant matter" that operates "outside and inside the human body" (Bennett 2010:xiv), and Kath Weston's attention to the "eco-intimacies" through which entities "infiltrate one another's very substance, materially and otherwise" (Weston 2017: 33). This productively expanded notion of embodiment encompassing as it does senses, affects, and materialities - underlies and informs the exploration, in Sections 4 and 5 below, of Chemical Valley workers' encounters with, and interactions about, occupational hazards.

\section{Sensory encounters with shop-floor hazards}

Well I've worked among the spitters and I've breathed the oily smoke

I've shoveled up the gypsum and it neigh 'on makes you choke

I've stood knee deep in cyanide, got sick with a caustic burn

Been working rough, I've seen enough to make your stomach turn.

And it's 'Go, boys, go'...

Verse from "The Chemical Workers' Song (Process Man)" by Great Big Sea ${ }^{6}$

During the second half of the 20th century, workers on the shop floors of Chemical Valley labored under conditions that put them into contact with noxious fumes, caustic acids, toxic liquids, and hazardous particles as they performed the labor of transforming resources into products. In refineries they converted crude oil into fuels; in petrochemical plants they synthesized compounds such as benzene, toluene, and xylene; in synthetic rubber plants they produced organic monomers that they then "polymerized" into rubber; and in foundries they worked with molten metal, sand and asbestos to create engine blocks. Workers' bodies were thus vulnerable to harm as these eco-intimacies of the workplace brought hazardous substances into contact with their skin, and into the interior of their bodies through skin, nose and mouth.

\footnotetext{
${ }^{6}$ https://www.youtube.com/watch?v=edAxujKev1Ihttps://www.youtube.com/watch?v=edAxujKev1I
} 
Sarnia's Holmes Complex, comprising several units, made extensive use of asbestos in all its operations. Former workers interviewed about their time at Holmes reported that "piles of raw asbestos and silica sand were stored in the yard, left uncovered"; the air was especially thick with these particles when the foundry doors were opened to relieve the stifling heat created by the iron-melting process and workers in the adjoining insulation unit were "blowing the asbestos off the equipment with air hoses" (quoted in Keith and Brophy 2004: 147). Under these conditions, toxic dust accumulated on the surfaces of machinery, as well as on the clothing of the workers who, at the end of the workday, carried it into the intimacy of the home. As the son of a Holmes worker stricken with mesothelioma poignantly recalls: "I remember when [my dad] came home from work.... He hung up his clothes and I marveled at the 'twinkle' of the dust in the air that surrounded [them]" (Keith and Brophy 2004: 148). Workers had very little control over their encounters with these particles; there was no ventilation in the facility, nor were there partitions between work areas, so while the workers were compelled to remain within their work space, silica and asbestos particles traveled freely through the air such that workers could not help but inhale them through the simple and necessary act of breathing.

Asbestos in the air, along with extreme heat, were constant threats to workers' health in other Chemical Valley facilities, as well. Donna, the widow quoted above, described to me the conditions for her husband Wayne when, as a young man in the late 1960s, he started work as a millwright at Welland Chemical: "They had a lunchroom you couldn't eat in because it was so nasty - there was asbestos floating in the air!." In addition, "Wayne used to have to do a 'beat down', where he'd climb on top of the furnaces and bang the top with a sledgehammer. There were times when the heat was so intense his shoes would melt to his feet." Extreme heat also created a climate in which the interactions between workers and the materials they handled become more intimate - and consequently more dangerous. The main substance produced by Welland was aluminum chloride, and as Donna described it:

There were chunks of that hanging off him all the time, and the heat of those furnaces - around a thousand degrees Fahrenheit - made him sweat. Sometimes he'd get scorched all down his arms and chest, because when chloride hits water, it turns into acid. (Interview, June 9, 2008)

At that time Welland, like many plants in Chemical Valley, did not have showers for the workers, thereby virtually ensuring that substances in contact with the skin would remain there for hours, where it could be absorbed into the body.

Other workers were in plants where they interacted with hazardous chemicals in liquid and gas form. A widow named Emily described her husband Bill's job at the Montell plant during the 1980s and 1990s. He worked in a unit that made propyl alcohol, and his role was as a process worker, which Emily explained means "lots of hands-on work with chemicals." ${ }^{7}$ Throughout his twenty years on the job, fumes from the chemicals used in processing assaulted Bill's nostrils on a daily basis. Then there were the occasional spills and leaks. After one especially hazardous incident, Bill said to Emily, "If anything happens to me, make sure you check into that incident report." Emily then described how Bill had died. In 1999, the two of them had taken a vacation in Mexico. Bill had been feeling fine throughout the trip until, on the way home, he experienced sudden and severe pain in his lower back. They went to the nearest hospital and "within 24 hours he had three organs shut down - they said it was severe pancreatitis - and he died"8 (Interview, July 10, 2008). In this case, Bill was able to perceive the chemicals in his work environment through smell, yet was not able to determine through his own senses which exposures, if any, posed health risks. Presumably, the incident report Bill had told Emily about contained scientific information that might have resolved this uncertainty, but she had been unable to find it.

\footnotetext{
${ }^{7}$ The excerpt from the Chemical Workers Song (Process Man), quoted at the beginning of this section, provides a vivid description of how this "hands-on work" could be experienced by workers.

${ }^{8}$ Although scientific studies dating back to the 1980s demonstrate strong correlations between exposure to industrial chemicals and diseases of the pancreas (e.g., Braganza, Jolley and Lee 1986), these diseases have not yet been officially designated as 'occupational' in Canada or the United States. See Brophy and Keith 2011 for a thorough examination of the complex web of factors that make it exceedingly difficult to establish causality between workplace conditions and cancers.
} 
Considering these examples, we see that in some cases workers were aware of brutal conditions, but not of the long-term effects on their health; in other cases, they might not have perceived the hazards at all. Either way, whether perceived at the time of exposure or not, substances that were absorbed, ingested, or inhaled into the interior of workers' bodies remained there for many years undetected. As described by phenomenologist Drew Leder (1990), internal organs "have a greatly decreased number and variety of sensory receptors compared to the surface body" (p. 40). In contrast to "touch, the most analogous form of surface perception", which "yields a panoply of ... sensations" (p. 40), the "inner body is marked by regional gaps, organs that although crucial for sustaining life, cannot be perceived" (p. 43). This changes, however, when organs eventually become so damaged that they can be felt as discomfort or pain; by this time, it is often too late for treatment to be effective.

We have seen how damage to Bill's pancreas was imperceptible over years of exposure, only to be felt intensely just before his death. The perception of disease can be delayed for even longer periods in the case of mesothelioma. Though Wayne likely inhaled the ultimately deadly asbestos particles from the time of his first job in the late 1960s, he continued to feel generally healthy for decades after that. Then, in the early 2000s, he was on a temporary job at a power generating plant when, as described by Donna, "He came home one day and said, 'Hon, I had trouble breathing today'." When he sought medical advice, the doctor told him, "There's something wrong with your lungs, and you've got a kidney tumor." (Interview, June 9, 2008). Wayne and Donna soon turned their attention from the kidney tumor to the lung problem when the latter was diagnosed as mesothelioma - Wayne died of that disease two years later. His death came almost 40 years after his first exposure to asbestos, yet only two years after he had felt the first symptoms of the disease.

In contrast to diseases with long latency periods is a threat that occurs immediately and with powerful force, causing serious injury, if not immediate death: that is, an explosion. As explained to me by Dave, a worker in his late fifties at the time of the interview:

The only time you'd have an exposure at the plant is when there's a leak inside the unit... But in other places, there's more danger of an explosion. In one place I worked there was a thousand pounds of pressure. An explosion actually happened there, and two guys got killed. (Interview, July 15, 2010)

Dave concludes in the resigned tone of someone still working in an industrial plant and who therefore needs to come to terms, at least to some extent, with the occupational hazards he faces daily. He explained that he prefers working where gases are released rather than where they are put under extreme pressure because: "The difference is between maybe getting an illness later in life, and not coming home tomorrow."

In these ways - through imperceptible conditions that could result in immediate dismemberment or death, as well as through the vibrant matter of toxic particles, caustic liquids, and noxious gases assaulting the senses and invading the body - workers routinely encountered serious threats to their health and their very lives throughout their years on the shop floors of Chemical Valley. At the same time, the risks posed by these threats - i.e., scientifically calculated probabilities of harm-remained unknown to them. As workers confronted these threats in the absence of reliable data regarding risk, their interactions within their community produced an ecology of affect that gave social meaning to their often-hazardous work.

\section{Affective encounters on the shop floor and beyond}

Given that the industrial facilities of Sarnia-Lambton were kept going by a workforce that was almost entirely male, workers' social interactions entailed reinforcement of a masculine identity. ${ }^{9}$ These gender norms and expectations, produced by and reinforced for workers through the ordinary affects of their daily interactions with one another and with family members, deflected attention away from concerns about the potential consequences of occupational hazards. One strong value of the male culture that pervaded the shop floor was the pride workers took in their ability to handle strenuous labor in unpleasant and even hazardous conditions.

\footnotetext{
${ }^{9}$ Although some positions within the plants during the 1960s, 1970s, and 1980s were held by women, the great majority of workers in the kinds of positions under discussion here were men (Adkin 1998:150-51), as were all of the workers I met or learned about during my research. I therefore focus my analysis on male workers.
} 
Retired pipefitter Gerald described an interaction that had occurred early in his work life at Polymer during the late 1960s, which served to alert him to these expectations:

In the early years, we younger guys were almost intimidated by the older folks. A lot of these guys were vets, and they'd put up with a lot worse than a little smell or a little dust. I remember complaining about the smell one time, and an older guy said to me, "Well, if you don't like that smell, you could always go get a job at the perfume counter at Sears!" (Interview, July 30, 2010)

This brand of ridicule, delivered on the shop floor by a senior worker who embodied the sacrifice, heroism, and courage of a World War II veteran, made a powerful impression on young Gerald, as evidenced by the fact that he shared this story with me nearly a half-century later.

Expectations of masculine identity could also constrain the actions of union representatives. Donna's husband, Wayne, had been active in his union at Welland Chemical, and when Donna and I were discussing the extreme heat conditions that had caused Wayne such suffering, I asked if his union had ever brought a health and safety grievance. Her reply: "Oh heavens no! They wouldn't grieve THAT! You know, 'That's just part of our work. If it's hot, take a salt pill'!"10 (Interview June 9, 2008)

Masculine values also entailed the expectation that a worker fulfill his role as provider for his family. For those who began their employment as young men during the 1960s, the senior members of the work force represented the first generation of Chemical Valley workers in Sarnia, and in many cases the younger workers were literally the sons and nephews of that first generation, thus lending a 'family tradition' aspect to this type of employment. These ordinary affects were further reinforced by the fact that, throughout the period under consideration here, industrial jobs in Chemical Valley paid significantly higher wages than similar jobs elsewhere in Canada, allowing a blue-collar worker there to provide his family with a middle-class lifestyle. Furthermore, in times of job insecurity workers were often even less likely than during prosperous times to complain about hazardous conditions in the plants. As described by Ed, a retired boilermaker for Shell Oil, "When you had a job you didn't question anything; you kept your head down, got your work done, got your paycheck and went home - that's the way it was." 11

We have seen how masculine stoicism could prevent unions from filing grievances over unsafe working conditions; a different ecology of affect emerged when workers did attempt to get safety concerns addressed and were thwarted by management personnel. Dave described an interaction he'd had in his role as union health and safety representative, when he had attempted to get a crucial safety issue related to the explosion resolved:

A hydrogen cloud had filled the area quickly, probably ignited by static electricity. They had a hydrogen expert come from a university, and one of his findings was that there was a lot of scaffolding in the way that might have prevented the guys from getting out in time. And there we were, starting up again with a lot of scaffolding in the way. When I pointed this out, management just says, "Oh, it doesn't really matter." (Interview July 15, 2010)

This exchange between Dave and "management" took place in the plant, next to the scaffolding that duplicated the physical conditions that had contributed to the deaths of two of his co-workers, thus making the apathy conveyed by a management representative all the more palpable.

\footnotetext{
${ }^{10}$ Other ethnographic examples of such working-class masculine identity markers include: manual workers in Sheffield, U.K. "who had a 'macho' attitude and were ashamed to admit to being afraid or tired at work" (Mollona 2009: 121); and copper miners in mid-20 $0^{\text {th }}$ century Montana who "took pride in the image of the hardworking, hard-drinking man who proved his masculinity each day in the hot, dark tunnels...beneath the ground" (Finn 1998: 100).

11 This quote, and several more to follow, are from a documentary film directed by Brett Story that was released in 2010. It focuses on the experience of living and working in Chemical Valley, and several of the interviewees in the film are known to me.
} 
Another factor that kept men working under difficult - even hazardous - conditions was the positive working-class identity they experienced from the tangible results of their labor, which in turn reinforced meaningful connections to family, community and place. A retired construction worker, Patrick, describes this in explicit terms:

I was raised here in Sarnia - it's pretty much a given you're gonna work in construction or in the plants. You go on a site and there's nothing there, and when you leave, something has been built...and it's usually pretty impressive. So, what does it mean to be working class? To me, it means contributing in a way you can actually see. I take a lot of pride in what I did-I can take my grandchildren to plants I've helped build and show them what I did. (Story 2010)

Similarly, Ed considers place and community in the context of the by-then well-established links between industrial work and terminal illness:

People live close to the refineries here. We're that interlinked with them. Do I want to leave this earth as just some guy who worked in the Valley, got sick and died? No, I don't. But the problem is...it's hard to say, "For my own health, I have to leave." (Story 2010)

This sense of connection to the area, the community, and even the work itself was all the stronger forty years ago, when the economy was booming and little was known by workers about the long-term health effects of shop-floor conditions.

As noted above, mesothelioma, pancreatic disease, kidney tumors, and other such life-threatening conditions were often not perceived by workers for years, as damage progressed internally. But can we assume they felt no hints of dis-ease throughout those long years, as exposures accumulated? An answer might be inferred from a study by Nicholas Shapiro (2015) of chronic domestic exposures to formaldehyde among residents in the United States. In contrast to the women he interviewed, who provided accounts of various "bodily dysfunctions" thought to be associated with formaldehyde, the men remained "actively indifferent to slight somatic abnormalities." That is, they "rejected the possibility that their bodies were permeable or vulnerable to chemical harm, thus also rejecting threats to masculine self-images." In this way, Shapiro concludes, "the denial of toxicity constitutes and is constituted by normative gender roles" (Shapiro 2015: 374). Given the ways in which Chemical Valley workers' experience was shaped by normative gender roles, it seems likely that they, too, may have remained indifferent to whatever "slight somatic abnormalities" they experienced, thus rejecting the possibility of serious harm until it was too late.

For the most part, workers' everyday interactions with family members reinforced ordinary affects that were positive: their willingness to take whatever job was available to support their families; the ability to endure hard physical labor and dangerous working conditions; and a sense of accomplishment when their labor resulted in useful structures and products. At the same time, negative affects emerged and were reinforced when older co-workers shamed junior colleagues into accepting noxious odors on the shop floor, or when workers were belittled by management's apathy toward conditions known to endanger workers' lives. All the while, as the eco-intimacy of the shop floor brought hazardous materialities into workers' bodies, where they ultimately morphed into catalysts of disease, workers remained for the most part unaware of these internal assaults - and to the extent they did perceive minor abnormalities, they likely disregarded them.

Both inside and outside the industrial plants, then, workers engaged in embodied affective encounters with co-workers and family members that provided alternative interpretations of the shop-floor conditions they encountered daily. In addition, workers experienced a deep attachment to community and place through the multiple ways in which they were "interlinked" with "the Valley." These factors are certainly relevant to understanding the relative lack of union activism and political advocacy that brutal working conditions typically incited in advanced Western nations between 1960 and 1990. Of even greater importance, however, were conditions stemming from the deep emplacement in Sarnia-Lambton of the petrochemical plants that 
dominated the local economy. Before exploring the emplacement of Chemical Valley industries, we consider the ways in which labor issues and environmental concerns did arise and were addressed in Ontario and around the Great Lakes during this period.

\section{Reflexivity begun: pollution, protest, and policy in Ontario, Canada}

By the time the industries of Chemical Valley reached peak production and influence in the early 1960s, Ontario (and virtually all other provinces in Canada) had established laws protecting bargaining rights for unions. In 1964 Ontario's Industrial Safety Act was passed into law, followed by the stronger Occupational Health and Safety Act of 1980, and strikes for wages and hours were common throughout the period under consideration here. Ontario also passed a series of environmental protection laws, most notably the Environmental Protection Act (1971) which created the Ministry of Environment in 1972, followed by the province's Environmental Assessment Act (1976). On the federal level Canada agreed, in 1972, to join with the U.S. in a bilateral agreement to control pollution in the Great Lakes, and Canada's Environmental Contaminants Act was signed into law in 1975. The Canadian Environmental Protection Act followed in 1988.

These legislative advancements took place in the context of growing public awareness of potential risks posed to human health and the environment by toxic emissions - an awareness that led to political pressure for government action. An early catalyst was a 1967 CBC documentary titled The Air of Death, which focused on the health effects of air pollution in Ontario. As a direct result of this documentary, students and faculty at the University of Toronto founded Pollution Probe, a grass-roots group concerned with the kinds of environmental health issues exposed by the film. Joined in the early 1970s by Greenpeace chapters as well as smaller local groups, Pollution Probe achieved a number of high-profile successes in Ontario throughout the 1970s and 1980s (O'Connor 2014).

These advances in occupational health and environmental protection in Canada were similar to - and in many cases patterned on - U.S. laws and policies (Hoberg 1990). At the same time, the United States, along with the United Kingdom, was turning toward policies of neoliberalism which held that the "fundamental mission [of the state] was to facilitate conditions for profitable accumulation" (Harvey 2005: 7). In contrast to the U.S and the U.K. where, during the 1980s, the "governments were running on avowedly [neoliberal] platforms", in Canada the transition started later and took longer (Russell 2000: 37); this was in part due to the fact that in Canada, all political parties more or less "accepted in practice if not in theory that Canada's is a mixed economy, and that the government has an important role in it" (Arthurs, Carter and Glasbeek 1984: 26). Ontario, however, distinguished itself from other provinces in the high value Ontarians placed on "the imperative pursuit of economic success" (Noel 1997: 53), thus bringing Ontario into closer alignment with the neoliberal values of the U.S. and U.K. Arguably the most extreme example of this philosophy of economic success over worker (and public) well-being transpired in Chemical Valley.

In this context it is notable that, although resistance to the effects of industrial hazards did arise in Sarnia-Lambton during the latter 20th century, these efforts could not be sustained. For example, although Sarnia was among the many Ontario cities that formed a chapter of Pollution Probe in the mid-1970s, this particular chapter was unable to achieve the successes enjoyed by other chapters, and by 1990 it had disbanded. ${ }^{12}$ With regard to unions, although there was a small but persistent group of workers who spoke out about hazardous conditions in the plants - most notably a Dow process worker and union leader named Ivan Hillier (his real name) who agitated about hazardous working conditions through the 1960s and 1970s (Adkin 1998: 168) - these efforts were not pursued through the union. Rather, the high-profile Hillier chose to fight those battles as a private citizen, due to concerns that the Labour Council would not have endorsed him had he asked (Adkin 1998: 172-173). And he might well have been correct in that assumption. In an in-depth analysis of unions' roles in Chemical Valley from the 1950s through the 1980s, Canadian political scientist Laurie Adkin argues that the homogeneity of the Chemical Valley industrial workforce - overwhelmingly white and

12 This failure is ironic in the extreme given the fact that The Air of Death, the documentary that inspired the founding of Pollution Probe, had focused on Chemical Valley as one of its two main case studies. 
male - made local unions such as the predominant Oil, Chemical, and Atomic Workers (OCAW) ${ }^{13}$ generally less likely than more diverse unions - for example, the Canadian Auto Workers (CAW) in nearby Windsor, Ontario - to join forces with other social movements toward shared goals. These demographics were a major factor in OCAW's trend toward "associational unionism" in which "close co-operation between union and management [is] aimed at achieving jointly-agreed goals", in contrast to the "social unionism" of CAW that sought deeper political change in Windsor plants during this same period (Adkin 1998: 156). In addition, several of the major industrial facilities in Chemical Valley remained ununionized during the 1960s, 1970s, and 1980s.

Unions and environmental groups in Toronto, Windsor, and other risk-industry hotspots throughout Ontario did, then, produce the political reflexivity predicted by Beck's model. But not in Chemical Valley. There, despite the extreme hazards within the plants and the obvious pollution that fowled the region's air and water, unions took a more associational approach in concert with management, and citizens' groups remained small and relatively ineffective compared with those in other parts of Southwestern Ontario. A necessary factor in suppressing these efforts was, I argue, the deep emplacement of petrochemical plants, and the corporations that owned and operated them, within a relatively small circumscribed area, thus creating a sense of permanence and belonging that further magnified and consolidated their power.

\section{Emplacement: locale, ecology, infrastructure}

In analyzing the industrial facilities of Chemical Valley as emplaced, I draw on a tripartite distinction between "location", "locale", and "sense of place", originally put forth by political geographer John Agnew. As summarized by Tim Cresswell: in contrast to location ("fixed objective coordinates" of a place "on the Earth's surface"), and sense of place ("the subjective and emotional attachment people have to place"), locale is "the material setting for social relations" (Cresswell 2015: 13-14). This dialectically conceived notion of locale, attending as it does to both material and social dynamics of place, underlies my analysis of the outsized role the petrochemical industry came to play in Sarnia-Lambton during the latter half of the 20th century. I argue that the natural ecology of the region, followed by the development of infrastructural networks, created a locale in which the deep emplacement of industry fostered and enhanced its political-economic power and influence there.

The region that came to be Southwestern Ontario was the territory of Anishinaabe peoples when the first French and English settlers arrived during the late 18th century. Drawn by the same features of water, land and climate that had sustained the Anishinaabe and other indigenous peoples before them, these Europeans established villages along the southeastern banks of Lake Huron and the eastern bank of the St. Clair River. Cutting away the forests of the interior to expose the rich topsoil that had been left behind as the last glaciers retreated, they established farms throughout the region. Over the course of the 19th century, resources under the surface of the land were discovered and exploited. First, the vast salt beds that had formed in subterranean caverns led to the establishment of several large-scale salt-mining operations. Later on, oil that bubbled up through fissures in the dense clay that lay just beneath the topsoil made possible the first viable oil well in North America, which began production in Lambton County in 1857. Ultimately, numerous drilling operations, along with refineries to process the oil, sprang up throughout the county.

Even as the oil fields of Southwestern Ontario began to dry up toward the end of the 19th century, the pipeline networks that had been built to transport oil locally were extended both eastward and westward. Railroads and highways were constructed, as well, connecting Sarnia with other parts of Ontario, and a tunnel under the St. Clair River that allowed trains to travel directly from Sarnia to Port Huron, Michigan, and beyond was completed in 1891. In 1938, the Bluewater Bridge was built over the St. Clair River, allowing easy passage across the international border. In addition, Great Lakes freighters were able, by the turn of the $20^{\text {th }}$ century, to navigate the St. Clair River and Sarnia Bay as a result of a series of dredging projects undertaken during the second half of the 19th century. These infrastructural developments not only connected Sarnia-Lambton and its industries to resources and markets throughout Canada, but also with those in the United States.

\footnotetext{
${ }^{13}$ OCAW restructured in the late 1970s and changed its name to the Energy and Chemical Workers Union (ECWU).
} 
The facility generally considered to be the flagship of Sarnia's modern petrochemical complex was Polymer, a state-owned plant established in 1942 to produce synthetic rubber during the Second World War. Economic historian Matthew J. Bellamy describes some of the geographical and ecological features that made Sarnia "the ideal location for this new industry":

There on the broad banks of the St. Clair River...the plant would have easy access to raw material and markets. The river itself would be a natural source of the comparatively low-temperature water needed for the plant's cooling system. (Bellamy 2007: 32)

Similarly, the natural salt beds that underlie Lambton County now provided a valuable resource for chemical plants that use chlorine in their operations. This was a key factor for the Dow Chemical branch plant that the Canadian government brought to Sarnia to provide the styrene necessary for Polymer's synthetic rubber production. In addition, Imperial Oil, Polymer, Dow, and similar facilities made use of the underground caverns, naturally lined with dense clay, as storage spaces for "feedstocks" (raw materials) and industrial waste.

This nascent petrochemical complex, then, can be considered as a locale in which each facility was deeply, materially connected with the water, oil, salt, and clay that formed the local ecology. In addition, these operations made 'social' connections with one another through the exchange of substances - one facility's waste was another facility's feedstock. The following paragraph from an informal history written by retired Dow executive R.W. Ford illustrates the complexity of these relationships:

In the late fifties [Imperial Oil added] a modern unit to produce ethylene, propylene and butadiene of very high purity. These building blocks were in turn sold to Dow and DuPont for production of polyethylene, and to Polymer operations for production of rubber. In one interchange, Esso Chemicals sends ethylene to Dow, which Dow reacts with chlorine to make vinyl chloride which it then sells to Esso to make polyvinyl chloride. Some of the PVC then returns to Dow in the form of electrical insulation and plastic pipe. (Ford 1987)

These material and social entanglements served to attract similar operations to Sarnia-Lambton, which in turn created additional links with underground structures and substances, as well as further exchanges of feedstocks and products among the plants.

By the early 1960s, the refineries, chemical plants, and factories that comprise Chemical Valley were well-established and thriving, and more such operations were added throughout the 1970s. Although several of the corporations represented there were Canadian, most were not. There were a number of multinationals that had resulted from mergers of Dutch corporations with British (Shell Oil), German (BASF), or U.S. (Montell) companies. But the majority of the facilities were branch plants of U.S.-based corporations, including: Dow, Esso, DuPont, Royal Polymers, Union Carbide, Suncor, and Cabot. The features that drew these foreign corporations to a primarily rural county in Ontario, Canada, were, as described above, ecological, geographical, and infrastructural. With each new petrochemical plant's arrival, the complex grew more interconnected, thereby becoming more deeply embedded in the material and social relations of this unique locale. Thus, in the 1970s, as corporations throughout the Great Lakes region began closing plants and pulling out of cities and towns on both sides of the border, collectively leading to the deindustrialized Rust Belt, the industrial complex in Sarnia stayed firmly rooted in place and the local economy remained relatively strong. ${ }^{14}$

The presence of dozens of corporations of the same economic sector, deeply embedded within a 25square-kilometer area, facilitated another development: the decision made among corporate executives to act as a unified force to further their common interests. That is, Chemical Valley offers an early - and exceptionally

\footnotetext{
${ }^{14}$ In a comprehensive historical analysis of the making of North America's Rust Belt on both sides of the Canada-U.S. border, Canadian historian Steven High (2003) explores workers' experiences of the deindustrialization that occurred between 1969 and 1984. One prominent industrial center absent from that analysis is Sarnia; I attribute this omission to the fact that Chemical Valley remained more-or-less intact during this period, and was therefore not relevant to High's study.
} 
successful - example of clustering, a term coined by business economist Michael E. Porter (1998) to refer to the formation of "critical masses - in one place - of unusual competitive success in particular fields" (p. 77). These geographic concentrations of companies increase their power by "encompassing an array of linked industries and other entities important to competition" (p. 77). Thus, although companies within a cluster compete to some degree with one another, "the proximity of companies and institutions in one location also fosters better coordination and trust" among them (p. 80). This in turn enhances the competitive advantage of those companies vis à vis others in the same sector but different locations. Porter lists "entities important to competition" with which clustered companies can establish ties as those that "provide specialized training, education, information, research, and technical support" (p. 78).

From the business perspective that Porter represents, these traits are positive and desirable in that they enhance the ability of businesses to influence social and political institutions that might otherwise set limits on their operations. From the perspective of those most vulnerable to harm from the unfettered activities of clustered risk industries, a more troubling picture emerges. In the following section we examine the extent to which the emplaced and clustered corporations of Sarnia-Lambton solidified their power in the region, resulting in an extreme form of Beck's "politics of knowledge", in which the public is unable to determine risks for themselves, therefore having to rely on "technical experts" to "assess the manageability of risks" (Beck 1992: 58). In this endeavor, the primary local news outlet of the period serves as a remarkably revealing lens on the power of local industry to manage "technical expertise", thereby controlling knowledge and shaping attitudes about their operations.

\section{Emplaced corporate power by and through the Observer newspaper}

The newspaper serving Sarnia-Lambton, called the Canadian Observer until the late 1960s and the Sarnia Observer thereafter, was the most widely available source of news and information about the local issues during the period under consideration here. ${ }^{15}$ Given the prominence of this organ and the objectivity expected of a newspaper, combined with the absence of any other regular source of information about the role of local corporations in the community, the Observer played a major role in controlling knowledge and shaping attitudes of workers and their families in Chemical Valley.

The Observer's pro-industry stance was most blatantly conveyed through editorials that took the side of local corporations on controversial issues, especially with regard to the industrial pollution that was obvious to the public by the early 1960s. For example, an editorial in August of 1964 titled "Sarnia's industry credit to the community" chides readers: "All too prevalent is the 'milch cow' attitude, which alternates between demands on the industry for this or that community cause, and grumbles at the inconvenience industry might cause (smoke, smell, noise, etc.)." Similarly, in a 1968 editorial titled "Air pollution study better than expected" (July 11), readers are informed that, despite some troubling statistics on local air pollution that had been released by national news outlets, residents need not worry because local corporations "intend to continue their extensive research into the problem", in the spirit of the "good corporate citizenship which our industries demonstrate."

These editorial opinions were supported with news stories and reports on the commitment of Chemical Valley industries to address local pollution problems. The following headlines, chosen from among hundreds of similar examples, serve to illustrate this approach: "\$700,000 Imperial Oil plant to curb smog peril" (July 28, 1964); "Sarnia pollution would be worse but for industry" (Dec 4, 1967); and bizarrely, in the wake of an international scandal in which mercury in Lake St. Clair and Lake Erie had been traced back to Dow Chemical in Sarnia, an article headlined "Dow cell shut-down means less mercury" commended Dow on its "global commitment to environmental excellence" (January 15, 1973).

${ }^{15}$ Although there were no local television or radio stations during this period, there were other sources of information: union newsletters, local papers of small towns, and occasional coverage of Chemical Valley issues by national news outlets. Still, the Observer remained throughout this period the only daily paper that served Lambton County as a whole, and was therefore the most influential news outlet in the region overall. 
In these ways, the Observer newspaper played a key role in cultivating pro-industry attitudes and values among the residents of Sarnia-Lambton, a large proportion of whom were workers and their families. Perhaps more troubling to the issues considered here, however, is the extent to which this influential local newspaper controlled public knowledge not only about everyday threats of human health due to industrial pollution, but also about the accidents that often injured and sometimes killed workers.

In reporting such incidents, the Observer invoked voices of expertise almost exclusively from two main sources, one of which was officials of the facility in question. For example, an article about a fire at the Imperial Oil Limited refinery "that sent flames and smoke billowing hundreds of feet into the air" is headlined "IOL fire rated minor"; the sole source of this "rating" is "Imperial's petroleum products manager" (September 25, 1969). And an article titled "Explosion rocks unit at CIL ammonia plant" reports that the blast, "heard 10 miles away", was followed by fire; and yet, the reader is assured there were "no environmental problems" resulting from this explosion and fire. The source of this reassurance is the plant manager. These articles are typical of similar ones that appeared with great regularity - at least once per month - throughout the period under consideration here. Furthermore, the company spokesperson nearly always stated that an investigation as to the cause was being launched. Despite an extensive search, however, I never succeeded in finding any reference to, let alone a full reporting of, the results of any of these 'investigations.'

The second source of 'expert opinion' the Observer relied on was a research group originally called the St. Clair River Research Committee (SCRRC), which later changed its name to the Lambton Industrial Society (LIS). In virtually every article related to industrial emissions, leaks, and accidents that I found in the Observer archives, the empirical data and scientific evidence used to support the claims were provided by the SCRRC/LIS. This exclusive reliance on one research organization is dubious at best; it passes entirely outside the bounds of credibility when one considers the nature of this organization.

The St. Clair River Research Committee was founded in 1952 by top officials from Polymer Corporation, Imperial Oil Limited, and Dow Chemical of Canada. This organization, the "first of its kind on the continent" (according to their initial report on air pollution, issued in 1954), grew rapidly and by 1960 a majority of the petrochemical corporations in Sarnia-Lambton had joined this industrial consortium. Although the Observer relied exclusively on the SCRRC/LIS as their source of scientific, authoritative information on air and water pollution in the region, the newspaper rarely if ever acknowledged any possible conflict of interest. Furthermore, the only institution of higher learning - and the place where reports on industrial pollution were produced and risks to human health and the environment were calculated - was Lambton College, which had been founded with funding from the petrochemical sector, and which included executives from local plants on its board of directors. Thus, the ideal of the cluster strategy as described by Porter - that industries within the same sector form ties with entities that provide specialized training, education, information, research, and technical support - was realized and exceeded by Chemical Valley corporate elites.

A series of Observer pieces in November of 1975 is quite telling in that it suggests (no doubt inadvertently) the extent to which Chemical Valley corporations - through their 'research group'-oversaw and managed information. The first article in the series reports on a study conducted by an independent Toronto consultant hired by a small town in Lambton County to test the air quality amid growing citizen concerns about increased sulfur dioxide from nearby industrial facilities. The article begins with the consultant's main finding, that "levels of sulfur dioxide over the area exceed the safety standard established by the government." It then, however, proceeds to emphasize the negative responses of local pro-industry elected officials who raise questions about the validity of the study. The article's headline, "MPPs ${ }^{16}$ to investigate report of polluted air", indicates that the concern is not with the pollution itself; rather, the problem is the fact that the level of pollution is being publicized (November 7, 1975). This was followed the next day by an editorial that questioned the consultants' findings while assuring readers that their local MPPs were going forward with an investigation into the situation. Twelve days later came an article reporting the results of these efforts. As it turned out - the reader is told - the consultant's initial conclusions had been drawn based on "outdated reports"; once he had been given more recent reports, he was able to see that the levels of sulfur dioxide were in fact safe. Those "more recent reports" were provided to him by the Lambton Industrial Society. The headline for this article

${ }^{16}$ Members of Provincial Parliament. 
proclaimed, in huge letters, "Consultant admits his remarks on pollution 'premature': no danger from levels of Sulphur Dioxide" (November 20, 1975).

Sarnia's petrochemical cluster also developed tactics for dealing with the Ontario Ministry of Environment, established in 1972 to promote clean and safe air, land, and water to ensure healthy communities. These tactics can be extrapolated from articles that appeared in the Observer starting in the mid-1970s. One that attends explicitly to the role of the Ministry of Environment is headlined "Lambton Industrial Society: industries keeping an eye on themselves", and begins with a statement and a question: "The life blood of Sarnia is the petrochemical industry - but who is watching to ensure the area's environment is not being sacrificed in exchange?" Then, while acknowledging that "Ontario's environment ministry is one such watch dog", the article quickly moves on to describe a "group whose objective is to control pollution", the Lambton Industrial Society. The LIS manager is then quoted explaining that "no one is going to pull the wool over the ministry of environment's eyes, whose people know what to expect and what causes pollution in this area" (May 10, 1979). At the same time, numerous articles of the period refer to the fact that the local Ministry of Environment office was relying on the LIS to provide and interpret all data on industrial emissions, spills, and other activities related to pollution. Thus, one might reasonably conclude that in fact, industry had no need to "pull the wool over the eyes" of their would-be regulators because the industry's own researchers controlled all relevant data to which the Ministry had access.

In these ways, the Observer constituted an aspect of the daily lived experience of workers (and their families) that, though less visceral than their shop-floor experiences or social interactions, none-the-less helped shape their attitudes and sensibilities regarding the role of industrial companies in the local community. These factors - in combination with the associational unionism that prevailed in the plants during this period, and masculine working-class values that imbued hazardous shop-floor conditions with positive meaning - left workers and their families with limited options for demanding change, and little incentive to do so.

Chemical Valley during the latter half of the $20^{\text {th }}$ century clearly constituted a Beckian risk society in the nature and extent of the threats it produced and the politics of knowledge that prevented the associated risks from being known by the public. At the same time, it escaped the political reflexivity that, according to the model, is virtually inevitable in "developed wealthy democracies" such as Canada. Based on empirical research, drawing on approaches to embodiment and emplacement that entail both materiality and meaning, and considering evidence of corporate power as revealed in and through the local newspaper, I have taken a political ecology approach to "unravel the political forces at work in the environmental transformations" (Robbins 2012: 3) of Sarnia-Lambton during the 1960s, 1970s, and 1980s. But what of the current situation, as the second decade of the 21st century draws to a close?

\section{Conclusion: reflexivity denied?}

My first engagement with these issues occurred in 2007, during a time of raised awareness and activism surrounding occupational diseases and environmental hazards: real change seemed not only possible, but imminent. As it turned out, however, those gains for workers and residents were short-lived, and Donna's ominous admonition as I began my interviews for this project in 2008 proved prescient. By 2016, most of the initiatives that had appeared so promising in 2007 had stalled, and in some cases had been reversed. At present, while the occupational health clinic remains in operation, it no longer serves as a community gathering space, and the type and degree of public advocacy that had characterized the clinic's role under former leadership is no longer practiced. Despite the impressive on-going efforts of a few intrepid individuals, citizens groups have diminished in size and influence. At the same time, the organization formerly known as the St. Clair River Research Society and then the Lambton Industrial Society has rebranded itself the Sarnia-Lambton Environmental Association; while no longer holding the near total control over scientific data that it enjoyed during the second half of the 20th century, this industrial consortium remains a key player in local politics. Even as some Chemical Valley plants have scaled back their operations, and a few of the prominent corporations of former times have finally pulled out entirely, a substantial cluster of heavily polluting facilities remains firmly emplaced in the land and on the water, connected to the infrastructure, and entrenched in the economic and civic life of Sarnia-Lambton. 
Most telling of all is the fate of the Lambton Community Health Study (LCHS) that I had found so promising on that July morning in 2007. In a 2016 Report to the community, the LCHS summarizes their work as follows: in Phase 1 (2008) they "established a governance model and board" composed of a variety of stakeholders [one prominent member of which was the Sarnia-Lambton Environmental Association]; Phase 2 (2009 - 2013) was devoted to a "review of the literature", several surveys and focus groups of residents, and a consideration of "ways to improve communication within Lambton County regarding industrial accidents, exposure levels, etc., or designate an appropriate body to do so"; and Phase 3 (2014 -2016) focused on "efforts to secure funding" to carry out the proposed scientific investigation - efforts that, the Report notes, were "ultimately unsuccessful." The LCHS concludes its Report to the community by emphasizing the "strong relationships and connections" that were built "between multiple stakeholders in pursuit of their goals" and recommending "continued engagement with researchers conducting relevant studies", while reassuring the community that as such studies are completed, "Lambton Public Health will communicate the information to community stakeholders."17

The perfect storm of conditions that formed during the 20th century and resulted in insulating Chemical Valley from environmentalist and union activism, though somewhat weakened in the 21st century, yet prevails. Even as the occupational disease epidemic continues unabated, even as industrial fires, explosions, spills, and leaks continue to occur on a regular basis, those who hold the dwindling number of well-paying industrial jobs are inclined to, paraphrasing retired Shell employee Ed, "keep their heads down, get their work done, get their paycheck, and go home." Meanwhile, families of stricken workers continue to be reluctant to engage in the "hell raising" tactics predicted by Beck's model until, as Wayne's widow Donna put it, the worker has died and "his family gets angry enough - and has nothing left to lose - that they're willing" to speak out. As the second decade of the 21st century draws to a close, it seems that for workers, their families, and other residents of Sarnia-Lambton, reflexivity delayed might well have atrophied into reflexivity denied.

\section{Postscript}

During the three years since this research project ended, an investigation was jointly undertaken by several media organizations (Toronto Star, Global News, National Observer), the Michener Awards Foundation, and the journalism schools of two universities (Ryerson and Concordia). This project has "documented a troubling frequency of industrial spills and leaks in Sarnia's Chemical Valley over a two-year period which raised serious concerns about government oversight of industry" (Jarvis and Russell 2017). The resulting series of articles and videos led to a commitment by Ontario's Ministry of Environment in October of 2017 to fund a reboot of the Lambton Community Health Study. At that time, the Liberal Party held the majority in Ontario; since then, the Conservative party has gained control, causing Sarnia City Counselor and former LCHS chair Anne Marie Gillis to wonder if the proposed study, which was scheduled to get underway in fall of 2019, will go forward "given recent [budget] cuts by the Doug Ford ${ }^{18}$ Conservatives" (Dentinger 2019). If the funding holds and the study proceeds ${ }^{19}$, will outside researchers be able to gather their own data, or will they be restricted to data provided by the industry consortium? Will the final result be actual, effective government oversight of industry to control emissions both within and outside the plants? In short, is Sarnia-Lambton finally on the brink of true political reflexivity and the change it promises? Only time will tell.

\footnotetext{
${ }^{17}$ The full LCHS report is available on line at https://lambtonpublichealth.ca/wp-content/uploads/2019/04/LCHS-Reportto-Community.pdf.

${ }^{18}$ Ontario Premier as of June, 2018.

${ }^{19}$ A tender was advertised for a Sarnia Area Environmental Health Project Air Exposure Review in October 2019: https://bit.ly/2WPKLyP and in Jan. 2020 the study was still anticipated (https://bit.ly/2UrKkZG).
} 


\section{References}

Adkin, L.E. 1998. Politics of sustainable development: citizens, unions, and the corporations. Montreal: Black Rose Books.

Arthurs, H.W., D.D. Carter, and H.J. Glasbeek. 1984. Labour law and industrial relations in Canada. $2^{\text {nd }}$ edition. Toronto: Buttersworth.

Barrios, R.E. 2017. Governing affect: neoliberalism and disaster reconstruction. Lincoln: University of Nebraska Press.

Beck, U. 1992. Risk society: towards a reflexive modernity. M.A. Ritter (trans.). New Delhi: Sage.

Beck, U. 1995. Ecological enlightenment: essays on the politics of the risk society. M.A. Ritter (trans.). Prometheus Books.

Bellamy, M.J. 2007. Profiting the crown: Canada's Polymer Corporation, 1942-1990. Montreal: McGillQueens University Press.

Bennett, J. 2010. Vibrant matter: a political ecology of things. Durham: Duke University Press.

Besnier, N. 1990. Language and affect. Annual Review of Anthropology 19: 419-451.

Braganza, J.M., J.E. Jolley and W.R. Lee. 1986. Occupational chemicals and pancreatitis: a link? International Journal of Pancreatology. May(1): 9-19.

Brophy, J.T. and M.M. Keith. 2011. Barriers to the recognition of occupationally related cancers. Journal of Risk and Governance 2(1): 5-25.

Cohen, B. (dir.). 2007. Toxic trespass. If You Love Your Children, Inc. Toronto: National Film Board of Canada.

Cresswell, T. 2015. Place: an introduction. $2^{\text {nd }}$ edition. West Sussex: Wiley Blackwell.

Csordas, T.J. 1994. Introduction: the body as representation and being-in-the-world. In Csordas, T.J. (ed.). Embodiment and experience: the existential ground of being. Cambridge: Cambridge University Press.

Dentinger, D. 2019. Sarnia area health study to begin this fall. Blackburn News, May 29, 2019. https://blackburnnews.com/sarnia/sarnia-news/2019/05/29/sarnia-area-health-study-begin-fall/

Dwyer, P.D. and M. Minnegal. 2006. The good, the bad and the ugly: risk, uncertainty and decision-making by Victorian fishers. Journal of Political Ecology 13: 1-23.

Finn, J.L. 1998. Tracing the veins: of copper, culture, and community from Butte to Chuquicamata. Berkeley. University of California Press.

Ford, R.W. 1987. History of the chemical industry in Lambton County. http://www.sarniahistoricalsociety.com/story/history-of-the-chemical-industry-in-lambton-county/, accessed on August 21, 2015.

Harvey, D. 2005. A brief history of neoliberalism. Oxford: Oxford University Press.

High, S. 2003. Industrial sunset: the making of North America's Rust Belt, 1969-1984. Toronto: University of Toronto Press.

Hoberg, G. 1991. Sleeping with an elephant: the American influence on Canadian environmental regulation. Journal of Public Policy 11(1): 107-131.

Jackson, D.D. 2010. Shelter in place: A First Nation community in Canada's 'Chemical Valley.' Interdisciplinary Environmental Review 11(4): 249-262.

Jackson, D.D. 2011. Scents of place: the dysplacement of a First Nations community in Canada. American Anthropologist 13(4): 606-618.

Jarvis, C. and A. Russell. 2017. Ontario government commits to fund study after 'Chemical Valley' investigation. Global News. October 16, 2017. https://globalnews.ca/news/3805442/ontariogovernment-commits-to-fund-health-study-after-chemical-valley-investigation.

Keith, M.M and J.T. Brophy. 2004. Participatory mapping of occupational hazards and disease among asbestos-exposed workers from a foundry and insulation complex in Canada. International Journal of Occupational and Environmental Health 10: 144-153. 
Leder, D. 1990. The absent body. Chicago: University of Chicago Press.

Little, P.C. 2013. Envisioning the political ecology of mitigation in a microelectronic disaster setting. Journal of Political Ecology 20(1): 217-236.

Lock, M. and J. Farquhar. 2007. Introduction. In Lock, M. and J. Farquhar (eds.). Beyond the body proper: reading the anthropology of material life. Durham: Duke University Press. Pp. 1-18.

MacDonald, E. and S. Rang. 2007. Exposing Canada's Chemical Valley: an investigation of cumulative air pollution emissions in the Sarnia, Ontario area. Toronto: Ecojustice Canada.

Mackenzie, C.A., A. Lockridge and M. Keith. 2005. Declining sex ratio in a First Nation community. Environmental Health Perspectives 113(10): 1295-1298.

Mollona, M. 2009. Made in Sheffield: an ethnography of industrial work and politics. New York: Berghahn.

Murphy, M. 2013. Distributed reproduction, chemical violence, and latency. The Scholar \& Feminist Online 11(3).

Noel, S. 1997. The Ontario political culture: an interpretation. In White, G. (ed.) The government and politics of Ontario, $5^{\text {th }}$ edition. Toronto: University of Toronto Press.

O'Connor, R. 2014. The first green wave: pollution probe and the origins of environmental activism in Ontario. Vancouver: University of British Columbia Press.

Parr, J. 2010. Sensing changes: technologies, environments, and the everyday, 1953-2003. Vancouver: University of British Columbia Press.

Payne, J.I. and E. Pichora. 2009. Filing for workers' compensation among Ontario cases of mesothelioma. Canadian Respiratory Journal 16(5): 148-152.

Porter, M.E. 1998. Clusters and the new economics of competition. Harvard Business Review Nov-Dec: 7790.

Reno, J. 2011. Beyond risk: emplacement and the production of environmental evidence. American Ethnologist 38(3): 516-530.

Robbins, P. 2012. Political ecology: a critical introduction. Cichester: Wiley-Blackwell.

Rodaway, P. 1994. Sensuous geographies: body, sense and place. London: Routledge.

Russell, B. 2000. From the workhouse to workfare: the welfare state and shifting politics terrains. In Burke, M., C. Mooers and J. Shields (eds.) Restructuring and resistance: Canadian public policy in an age of global capitalism. Halifax: Fernwood Publishing.

Scott, D. 2008. Confronting chronic pollution: a socio-legal analysis of risk and precaution. Osgoode Hall Law Journal 46(2): 293-343

Shapiro, N. 2015. Attuning to the chemosphere: domestic formaldehyde, bodily reasoning, and the chemical sublime. Cultural Anthropology 30(3): 368-393.

Skoggard, I. and A. Waterston. 2015. Introduction: toward an anthropology of affect and evocative ethnography. Anthropology of Consciousness 26(2): 109-120.

Stewart, K. 2007. Ordinary affects. Durham: Duke University Press.

Stoller, P. 1997. Sensuous scholarship. Philadelphia: University of Pennsylvania Press.

Story, B. (dir.). 2010. Land of destiny. Canadian Council for the Arts. DVD.

Thien, D. 2005. After or beyond feeling: a consideration of affect and emotion in geography. Area 37(4): 450456.

Weston, K. 2017. Animate planet: making visceral sense of living in a high-tech ecologically damaged world. Durham: Duke University Press.

Wiebe, S. 2016. Everyday exposure: Indigenous mobilization and environmental justice in Canada's Chemical Valley. Vancouver: UBC Press. 